\title{
PENGEMBANGAN BUKU AJAR TEMATIK INTEGRATIF BERBASIS DISCOVERY LEARNING DALAM PENINGKATAN MOTIVASI BELAJAR DAN KARAKTER TANGGUNG JAWAB
}

\author{
Arief Budi Permana, Pratiwi Pujiastuti \\ Program Pascasarjana Universitas Negeri Yogyakarta \\ email: Ariefpermana09@yahoo.com, pratiwi@uny.ac.id
}

\begin{abstract}
Abstrak : Penelitian ini bertujuan menghasilkan dan mengetahui keefektifan buku ajar pada pembelajaran tematik integratif berbasis discovery learning subtema Sumber Energi kelas III SD Negeri 4 Krandegan Banjarnegara. Penelitian ini merupakan penelitian dan pengembangan (R\&D). Pengumpulan data menggunakan pedoman wawancara, lembar penilaian produk buku ajar, lembar pengamatan motivasi belajar dan karakter tanggung jawab, angket motivasi dan karakter tanggung jawab, angket respons guru, angket respons peserta didik. Teknik analisis data menggunakan uji t dengan taraf signifikansi 0,05 . Hasil penelitian menunjukkan aspek materi yang memperoleh skor 166 dengan kategori "baik", aspek media memperoleh nilai 95 dengan kategori "sangat baik", respons guru memperoleh nilai 69 dengan kategori "sangat baik", respons peserta didik memperoleh 9,82 dengan kategori "sangat baik". Keefektifan dapat dilihat dari observasi karakter tanggung jawab peserta didik kelas eksperimen 1 dan eksperimen 2 memperoleh skor 18,5 dan 15,78. Hasil angket motivasi belajar peserta didik kelas eksperimen 1 dan eksperimen 2 memperoleh skor 58,71 dan 60,5 .
\end{abstract}

Kata Kunci: buku ajar tematik integratif berbasis discovery learning, motivasi belajar, karakter tanggung jawab

\section{DEVELOPING INTEGRATIVE THEMATIC A TEXTBOOK BASED ON DISCOVERY LEARNING TO ENHANCE MOTIVATION LEARNING AND CHARACTER RESPONSSIBILITY}

\begin{abstract}
This research aims to produce and determine the effectiveness of integrative thematic an textbook based on discovery learning subthema "Sumber Energi" class III Student SDN 4 Krandegan. Collecting data used interview guides, product assessment sheet textbook, observation sheet motivation to learn and character responssibility, teacher questionnaire, the questionnaire responsses of learners. Data were analyzed using t test with significance level of 0.05 . The results showed the aspect of material obtained a score of 166 with the "good" category, media aspects scored 95 with the category of "very good", the responsse of teachers scored 69 in the category of "very good", the responsse of students also gained 9.82 by category "very good". The effectiveness can be seen from the observation of the learning motivation of students in the experimental class 1 and experiment 2 obtained a score of 18.67 and 16.07, while the character of responssibility observation learners of the experimental class 1 and 2 obtained a score of 18.5 and 15.78. The results of learners' learning motivation questionnaire of the experimental class 1 and experiment 2 obtained a score of 58.71 and 60.5 .
\end{abstract}

Keywords: integrative thematic a textbook based on discovery learning, motivation learning and character responssibility 


\section{PENDAHULUAN}

Tujuan dan fungsi pendidikan diamanatkan dalam Undang-Undang No. 20 Tahun 2003 tentang Sistem Pendidikan Nasional. Pada Pasal 3 UU ini disebutkan bahwa pendidikan bertujuan untuk mengembangkan kemampuan dan membentuk watak serta peradaban bangsa yang bermartabat dalam rangka mencerdaskan kehidupan bangsa, untuk berkembangnya potensi peserta didik agar menjadi manusia yang beriman dan bertakwa kepada Tuhan Yang Maha Esa, berakhlak mulia, sehat, berilmu, cakap, kreatif, mandiri, dan menjadi warga negara yang demokratis serta bertanggung jawab. Pendidikan nasional mengembangkan seluruh potensi diri manusia Indonesia secara utuh yang mencakup aspek sikap, keterampilan, dan pengetahuan. Tercapainnya tujuan pendidikan tersebut diharapkan membawa keberhasilan dalam kemajuan ilmu pendidikan dan tekhnologi.

Keberhasilan dalam pembelajaran tidak lepas dari semua komponen yang ada dalam pembelajaran. Adapun komponen-komponen pembelajaran meliputi tujuan, materi pelajaran, kegiatan pembelajaran, metode, alat dan sumber, serta evaluasi (Djamarah \& Zain, 2010: 41). Sebagai suatu sistem, komponen pembelajaran tersebut saling terkait antara satu dengan yang lainnya. Ketika ingin mengetahui tercapainya tujuan dalam pembelajaran maka harus dilaksanakan evaluasi. Guru memberikan evaluasi harus diawali dengan menyampaikan materi pelajaran dengan metode tertentu sesuai kebutuhan. Guru dalam menyampaikan materi pelajaran, membutuhkan sumber belajar guna menunjang keberhasilan proses pembelajaran.

Buku ajar sebagai sumber belajar merupakan komponen yang harus ada, karena buku ajar harus dikaji, dicermati, dipelajari, dan dijadikan bahan materi yang akan dikuasai oleh peserta didik dan sekaligus dapat memberikan pedoman untuk mempelajarinya. Buku ajar merupakan faktor eksternal peserta didik yang mampu memperkuat motivasi internal untuk belajar. Salah satu cara pembelajaran yang mampu memengaruhi aktivitas pembelajaran adalah dengan memasukkan buku ajar dalam aktivitas tersebut. Buku ajar yang didesain secara lengkap, dalam arti terdapat unsur media dan sumber belajar yang memadai akan memengaruhi suasana pembelajaran sehingga yang terjadi pada diri peserta didik akan lebih optimal. Buku ajar yang didesain secara bagus dan dilengkapi isi dan ilustrasi yang menarik akan menstimulasi peserta didik untuk memanfaatkan buku ajar sebagai sumber belajar.

Implementasi Kurikulum 2013 diwujudkan dalam pembelajaran Tematik Integratif. Pembelajaran Tematik Integratif merupakan sebuah pembelajaran yang mengintegrasikan atau memadukan berbagai kompetensi dari berbagai mata pelajaran ke dalam berbagai tema (Majid, 2014: 86). Jadi, setiap tema yang akan dipelajari memuat beberapa kompetensi dari berbagai mata pelajaran yang saling terkait. Penerapan pembelajaran Tematik Integratif guru perlu mengemas atau merancang pengalaman belajar yang dapat memengaruhi kebermaknaan belajar peserta didik.

Penerapan pembelajaran Tematik Integratif di sekolah dasar dapat membantu peserta didik, karena sesuai dengan tahap perkembangan peserta didik yang masih beranggapan bahwa segala sesuatu sebagai satu keutuhan. Pembelajaran pada hakikatnya merupakan suatu yang memungkinkan peserta didik baik secara individual maupun kelompok aktif mencari, menggali, dan menemukan konsep serta prinsip secara holistik dan otentik, sehingga diharapkan mampu melahirkan peserta didik yang kreatif, cerdas, dan inovatif.

Berdasarkan hasil need analysis melalui wawancara dengan guru kelas III SD Negeri 4 Krandegan Kabupaten Banjarnegara yang telah berusaha menerapkan Kurikulum 2013, menjelaskan bahwa ketersediaan buku pelajaran yang ada dari pemerintah sudah ada, namun buku tersebut hanya sebagai pinjaman saja, sehingga peserta didik hanya menggunakan buku tersebut ketika berada di sekolah. Materi penunjang yang ada di buku Kurikulum 2013 materi cakupannya terlalu luas, ada juga materi yang hanya sedikit sehingga guru berupaya rajin mencari materi dari internet dan juga buku ajar lainnya sebagai bahan acuan untuk memperdalam materi yang diajarkan dalam proses pembelajaran, meskipun mencari materi yang bersumber pada buku-buku sebagai referensi, namun tetap berpedoman pada silabus.

Guru kelas III menyampaikan bahwa selain buku ajar yang bersifat pinjam dari pemerintah, materi pembelajaran yang sulit khususnya pada subtema Sumber Energi berdampak pada motivasi belajar peserta didik, karena pada buku ajar subtema tersebut tidak adanya petunjuk yang menginginkan peserta 
didik melakukan sebuah percobaan langsung. Informasi-informasi yang ada didalam buku ajar dirasa sulit dipahami. Hal ini ditandai dengan penjelasan yang sudah diberikan guru namun pada saat guru memberikan pertanyaan sebagai umpan balik peserta didik ragu-ragu dalam menjawabnya. Motivasi belajar perlu adanya tindakan dari guru untuk merangsang peserta didik. Sebagaimana penjelasan yang dikemukakan Arends (2012: 142 bahwa motivasi biasanya didefinisikan sebagai proses merangsang atau membangkitkan perilaku yang digunakan untuk mengambil tindakan.

Tanggung jawab peserta didik kelas III juga disampaikan guru kelas bahwa dalam mengerjakan tugas yang diberikan guru masih kurang, sebagai contoh pada saat peserta didik diberikan tugas yang mengacu dari buku ajar, peserta didik tidak langsung mengerjakan. Latihan soal di buku ajar yang dirasa sulit menjadi faktor penyebab peserta didik dalam menunda pekerjaannya, dengan terlebih dahulu menunggu instruksi dan petunjuk pengerjaan soal dari guru. Hal ini menandakan bahwa buku ajar yang dirasa sulit dipahami peserta didik, menjadikan tanggung jawab peserta didik kurang dalam menyelesaikan tugas yang diberikan oleh guru.

Penerapan Kurikulum 2013, salah satu model belajar yang digunakan adalah dengan menggunakan model pembelajaran discovery learning. Dengan memasukkan model pembelajaran tersebut pada buku ajar yang digunakan dalam proses pembelajaran, diharapkan menjadikan peserta didik mempunyai motivasi belajar dalam dirinya. Model pembelajaran discovery learning peserta didik menekankan pada konsep atau prinsip yang sebelumnya tidak diketahui, dengan arahan guru untuk senantiasa membimbing peserta didik untuk memecahkan masalah dalam suatu permasalahan tertentu. Pengertian discovery learning dijelaskan seperti berikut ini.

Discovery learning has several advantages. It arouses students curiosity, motivating them to continue to work until they find answers. Students also learn independent problem-solving and criticalthinking skills, because they must analyze and manipulate information (Slavin, 2006: 245).

Pengertian discovery learning yang dikemukakan Slavin dapat diartikan bahwa pembelajaran penemuan memiliki beberapa keunggulan. Keunggulan tersebut di antarannya adalah peserta didik memiliki rasa ingin tahu, dapat memotivasi peserta didik untuk terus bekerja sampai menemukan jawaban. Peserta didik juga belajar pemecahan masalah dalam dirinya sendiri dan memiliki keterampilan berpikir kritis, karena ia harus menganalisis dan memanipulasi informasi. Implikasi dari definisi tersebut adalah penerapan model discovery learning diharapkan mampu membangkitkan motivasi belajar peserta didik untuk terus bekerja sampai mampu menyelesaikan permasalahan yang dihadapi. Model belajar dengan discovery learning juga diharapkan mampu menjadikan pribadi dalam diri peserta didik menuju pada pembentukan manusia yang seutuhnya, terutama dalam pembentukan karakter tanggung jawab pada diri peserta didik. Hal ini didukung dengan pendapat Lauermann \& Karabenick (2012: 13) bahwa "Responssibility can be approachoriented (to produce an outcome) or avoidanceoriented (to prevent an outcome), and it can refer to past, present, or future events". Artinya, tanggung jawab dapat dikatakan pendekatan berorientasi (untuk menghasilkan suatu hasil) atau penghindaran berorientasi (untuk mencegah hasil), dan dapat merujuk pada masa lalu, sekarang, atau peristiwa di masa depan.

Dari hasil wawancara juga diketahui bahwa permasalahan yang terjadi pada kelas III SD Negeri 4 Krandegan adalah motivasi belajar dan karakter tanggung jawab peserta didik masih perlu di perhatikan demi tercapainya proses pembelajaran yang optimal. Guru kurang mampu mengembangkan buku secara mandiri. Hal ini dikarenakan guru kurang mendapat pendampingan untuk mengembangkan buku secara mandiri serta keterbatasan waktu yang dimiliki oleh guru. Berdasarkan permasalahan yang ada, guru kelas III sangat membutuhkan buku ajar. Buku ajar yang dibutuhkan khususnya adalah buku ajar untuk subtema Sumber Energi.

Dari hasil observasi pada saat proses pembelajaran, terlihat bahwa belum tersedianya buku selain dari pemerintah yang digunakan dalam proses pembelajaran. Peserta didik disuruh oleh guru membaca buku, namun masih ada beberapa yang asik mengobrol dengan teman sebangkunya, sehingga pada saat proses pembelajaran belum maksimalnya penggunaan buku sebagai sumber belajar yang efektif. Pengamatan lain terlihat peserta didik harus 
menyalin soal yang ada di buku ajar sebelum mengerjakannya, sehingga banyak menghabiskan waktu dalam proses pembelajaran.

Melalui buku ajar Tematik Integratif berbasis discovery learning diharapkan dapat membantu guru dan peserta didik dalam melaksanakan proses pembelajaran. Buku ajar yang dikembangkan dengan fullcolor dan dilengkapi dengan informasi pendukung, latihan, dan langkah kerja yang jelas untuk memudahkan peserta didik dalam memahami materi, buku ajar yang dirancang dengan materi yang menarik dan terkini, buku ajar yang dapat dijadikan buku interaktif bagi peserta didik. Hal ini sesuai dengan karakteristik discovery learning yang dikemukakan Cruickshank, Jenkins \& Metcalf (2012: 283) yaitu guru perlu merancang situasi dan mengeksplorasi penghargaan supaya peserta didik mampu berpartisipasi dalam interaksi sehingga diharapkan menemukan hal-hal seperti pengetahuan untuk diri mereka sendiri dari tatanan tingkat yang lebih tinggi seperti menganalisis, mensintesis dan mengevaluasi. Dengan mengacu pada karakteristik discovery learning diharapkan buku ajar yang dikembangkan mampu meningkatkan motivasi belajar dan karakter tanggung jawab peserta didik.

Penelitian ini bertujuan untuk menghasilkan buku ajar Tematik Integratif. Buku ajar yang dikembangkan merupakan buku peserta didik kelas III SD dengan subtema "Sumber Energi" berbasis Discovery learning. Buku ajar yang dikembangkan diharapkan layak dan efektif digunakan untuk meningkatkan motivasi belajar dan karakter tanggung jawab peserta didik kelas III SD Negeri 4 Krandegan.

\section{METODE}

Penelitian ini menggunakan penelitian dan pengembangan atau Research and Development (R\&D). Pengembangan dilakukan mengacu pada model pengembangan Borg \& Gall (1983: 775) melalui 10 tahapan. Tahapan tersebut meliputi research and information collecting, planning, develop preliminary form of product, preliminary field testing, main product revision, main field testing, operational product revision, operational field testing, final product revision, dissemination, dan implementation. Penelitian ini dimulai pada bulan September 2015 sampai dengan bulan Januari 2016 di SD Negeri 4 Krandegan di Kabupaten Banjarnegara.
Subjek coba dalam penelitian dan pengembangan ini adalah sebagai berikut: Uji coba lapangan awal sebanyak 3 orang peserta didik kelas IIIA SD Negeri 4 Krandegan dan satu orang guru kelas IIIA SD Negeri 4 Krandegan. Uji coba lapangan sebanyak 10 orang peserta didik kelas IIIA SD Negeri 4 Krandegan dan satu orang guru kelas III A SD Negeri 4 Krandegan. Uji coba pelaksanaan lapangan sebanyak tiga kelompok yaitu dua kelompok sebagai kelompok eksperimen dan satu kelompok sebagai kelompok kontrol. Kelompok eksperimen dilakukan di kelas IIIA dan IIIC SD Negeri 4 Krandegan yang masing-masing berjumlah 28 peserta didik, dan kelas III B SD Negeri 4 Krandegan yang berjumlah 28 peserta didik sebagai kelompok kontrol, dan tiga orang guru kelas III A, B, dan C SD Negeri 4 Krandagan sebagai pelaksana pembelajaran.

Pengembangan buku pelajaran dengan model Borg \& Gall ini, hanya digunakan langkah penelitian 1 sampai 10 yaitu (1) Penelitian dan Pengumpulan Data, dengan melakukan studi pendahuluan (need analysis) ini meliputi studi literatur, observasi, wawancara dan analisis dokumen. (2) Perencanaan penelitian, dengan mengidentifikasi masalah, merumuskan masalah, merumuskan tujuan penelitian, melakukan diskusi dengan guru kelas terkait permasalahan yang ada dalam materi pada buku ajar tematik integratif, mengidentifikasi karakteristik peserta didik usia SD, mengidentifikasi permasalahan dalam penggunaan buku ajar yang digunakan guru dan peserta didik dalam proses pembelajaran, mengumpulkan sumber-sumber atau bahan-bahan tentang materi yang akan digunakan dalam pembuatan buku ajar tematik integratif, memperkirakan dana, tenaga, dan waktu, merencanakan pelaksanaan uji coba buku ajar tematik integratif berbasis discovery learning dengan bermusyawarah kepada kepala sekolah, guru kelas, pada saat uji coba produk dilaksanakan. (3) Pengembangan Draf Produk, dilakukan dengan pembuatan produk dan penilaian yang dilakukan oleh ahli. (4) Uji Coba Lapangan Awal, dilakukan dengan memilih 3 peserta didik dan memberikan lembar angket respons untuk mengetahui kelayakan buku ajar tematik integratif. (5) Revisi Hasil Uji Coba Lapangan Awal, dilakukan dengan merevisi terhadap produk buku ajar tematik integratif berbasis discovery learning sesuai dengan data, saran, dan masukan yang telah diperoleh sebelumnya. (6) Uji Coba Lapangan, dilakukan 
dengan memilih 10 peserta didik dan memberikan lembar angket respons kepada peserta didik dan guru. (7) Revisi Hasil Uji Coba Lapangan, dilakukan dengan merevisi produk buku ajar tematik integratif dilakukan dengan menganalisis data yang diperoleh dari uji coba lapangan. (8) Uji Pelaksanaan Lapangan, dilakukan dengan menggunakan metode penelitian quasi eksperimen dengan rancangan pre-test post-test control group design. (9) Penyempurnaan Produk Akhir, dilakukan dengan menganalisis data yang telah diperoleh dari analisis data berdasarkan hasil uji pelaksanaan lapangan. (10) Diseminasi, dilakukan sebatas kepada para guru di SD Negeri 4 Krandegan yang terdiri atas 15 kelas.

Teknik Analisis Data

\section{Data Kelayakan Produk}

Langkah-langkah analisis data kelayakan buku ajar tematik integratif berbasis discovery learning yang dilakukan di antarannya adalah (1) Melakukan tabulasi semua data yang diperoleh dari validator untuk setiap aspek dan indikator dari butir penilaian yang tersedia dalam instrumen penilaian. (2) Menghitung skor total rata-rata dari setiap aspek dan indikator. (3) Mengubah skor rata-rata menjadi nilai dengan kriteria skala lima dengan kategori pilihan tanggapan yaitu 5 untuk sangat baik, 4 untuk baik, 3 untuk kurang baik, 2 untuk baik, 1 untuk sangat kurang baik. Adapun kriteria kelayakan buku ajar oleh ahli meliputi aspek materi, aspek media, respons guru dan peserta didik terlihat pada tabel 1 , tabel 2 , tabel 3 , dan tabel 4 berikut.

Tabel 1. Kriteria Kelayakan Buku Ajar Tematik Integratif Aspek Materi

\begin{tabular}{ccc}
\hline Aspek Materi & Nilai & Kategori \\
\hline $168,09<\mathrm{X}$ & $\mathrm{A}$ & Sangat Baik \\
$136,03<\mathrm{X} \leq 168,10$ & $\mathrm{~B}$ & Baik \\
$103,97<\mathrm{X} \leq 136,03$ & $\mathrm{C}$ & Cukup Baik \\
$71,90<\mathrm{X} \leq 103,97$ & $\mathrm{D}$ & Kurang Baik \\
$\mathrm{X} \leq 71,90$ & $\mathrm{E}$ & Tidak Baik \\
\hline
\end{tabular}

Tabel 2. Kriteria Kelayakan Buku Ajar Tematik Integratif Aspek Media

\begin{tabular}{ccc}
\hline Aspek Media & Nilai & Kategori \\
\hline $92,45<\mathrm{X}$ & $\mathrm{A}$ & Sangat Baik \\
$74,81<\mathrm{X} \leq 92,45$ & $\mathrm{~B}$ & Baik \\
$57,18<\mathrm{X} \leq 74,81$ & $\mathrm{C}$ & Cukup Baik \\
$39,54<\mathrm{X} \leq 57,18$ & $\mathrm{D}$ & Kurang Baik \\
$\mathrm{X} \leq 39,54$ & $\mathrm{E}$ & Tidak Baik \\
\hline
\end{tabular}

Tabel 3. Kriteria Kelayakan Buku Ajar Tematik Integratif Respons Guru

\begin{tabular}{ccc}
\hline Respons Guru & Nilai & Kategori \\
\hline $58,83<X$ & A & Sangat Baik \\
$47,61<X \leq 58,83$ & B & Baik \\
$36,39<X \leq 47,61$ & C & Cukup Baik \\
$25,17<X \leq 36,39$ & D & Kurang Baik \\
$X \leq 25,17$ & E & Tidak Baik \\
\hline
\end{tabular}

Tabel 4. Kriteria Kelayakan Buku Ajar Tematik Integratif Respons Peserta Didik

\begin{tabular}{ccc}
\hline $\begin{array}{c}\text { Respons Peserta } \\
\text { Didik }\end{array}$ & Nilai & Kategori \\
\hline $8,00<\mathrm{X}$ & $\mathrm{A}$ & Sangat Baik \\
$6,00<\mathrm{X} \leq 8,00$ & $\mathrm{~B}$ & Baik \\
$3,99<\mathrm{X} \leq 6,00$ & $\mathrm{C}$ & Cukup Baik \\
$1,99<\mathrm{X} \leq 3,99$ & $\mathrm{D}$ & Kurang Baik \\
$\mathrm{X} \leq 1,99$ & $\mathrm{E}$ & Tidak Baik \\
\hline
\end{tabular}

Dalam penelitian ini, kelayakan buku ajar tematik integratif berbasis discovery learning dengan subtema "Sumber Energi" untuk peserta didik kelas III SD ditentukan dengan kategori baik. Jadi jika hasil penilaian masing-masing aspek adalah baik, maka produk pengembangan ini dianggap layak digunakan.

\section{Data Keefektifan Produk}

Proses evaluasi terhadap efektivitas produk dilakukan untuk mengetahui dampak penggunaan buku ajar tematik integratif berbasis discovery learning subtema Sumber Energi untuk mengetahui motivasi belajar dan karakter tanggung jawab peserta didik kelas III SD. Langkah pendahuluan dilakukan dengan melakukan observasi awal pada proses pembelajaran sebelum diaplikasikan buku ajar tematik integratif berbasis discovery learning. Sedangkan setelah dilakukan uji lapangan dilakukan observasi akhir. Analisis observasi awal dan observasi akhir akan menghasilkan nilai efektivitas penggunaan buku ajar tersebut.

Pada penelitian ini untuk melihat perbedaan motivasi belajar dan karakter tanggung jawab dilakukan dengan menggunakan uji t. Uji t dilakukan dengan bantuan program SPSS 16 for windows dengan taraf signifikasi 5\%. Kriteria keputusan yang digunakan yaitu tolak $\mathrm{H}_{0}$ jika nilai siginifikansi lebih kecil dari 0,05. Kriteria 
penerimaan atau penolakan $\mathrm{H} 0$ pada taraf signifikansi $5 \%$, yaitu:

$\mathrm{H} 0$ ditolak apabila $-\mathrm{t}$ hitung $<-\mathrm{t}$ tabel atau $\mathrm{t}$ hitung $<$ tabel dan skor signifikansi $<$ taraf signifikansi 0.05 .

$\mathrm{H} 0$ diterima apabila $-\mathrm{t}$ hitung $>-\mathrm{t}$ tabel atau $\mathrm{t}$ hitung $>$ tabel dan skor signifikansi $>$ taraf signifikansi 0.05 .

Keefektifan produk yang dikembangkan dapat dilihat dari hasil kriteria pengujian, apabila terdapat perbedaan hasil pengamatan motivasi belajar dan karakter tanggung jawab antara dua kelas (kelas kontrol dan kelas eksperimen), dan apabila hasil pengamatan motivasi belajar dan karakter tanggung jawab kelas eksperimen lebih besar dari kelas kontrol, maka produk yang dikembangkan dinyatakan efektif.

\section{HASIL DAN PEMBAHASAN}

Hasil pengembangan ini berupa buku ajar tematik integratif berbasis discovery learning subtema Sumber Energi untuk peserta didik kelas III SD. Berdasarkan penelitian yang dilakukan oleh dilakukan oleh Treadwell (2010: 58) dinyatakan bahwa ada signifikan perbedaan dalam mendukung kelompok eksperimen yang diajar menggunakan model discovery learning di prestasi akademik, persepsi penyelidikan, dan penyimpanan informasi, baik kognitif dan afektif. Hasil peneletian lain yang dilakukan oleh Busch et.al., (2009) menyatakan bahwa penggunaan buku ajar tematik berhasil menghubungkan beberapa mata pelajaran yang dapat mengembangkan sikap peserta didik.

Kelengkapan buku juga perlu diperhatikan dalam penyusunannya yaitu cover (sampul buku), prelimenaries (halaman pendahuluan), text matter (bagian utama), dan postlimenaritas (bagian penutup). Bagian-bagian tersebut merupakan bagian yang harus ada ketika menyusun buku ajar, sehingga nantinya akan menjadi buku yang memiliki struktur yang lengkap dan dapat digunakan pada saat proses pembelajaran.

Setelah produk awal buku ajar tematik integratif berbasis discovery learning subtema Sumber Energi untuk peserta didik kelas III SD selesai di buat, peneliti melakukan validasi produk kepada dosen ahli. Data validasi ahli diperoleh dengan memberikan produk awal yang berupa buku ajar tematik integratif berbasis discovery learning subtema Sumber Energi yang layak untuk peserta didik kelas III SD kepada dua orang dosen yaitu Dr. Insih Wilujeng (ahli materi) dan Dr. Ali Muhtadi. (ahli media).

Data yang diperoleh merupakan hasil penilaian ahli terhadap kualitas buku ajar tematik integratif berbasis discovery learning subtema Sumber Energi yang dikembangkan. Melakukan perbaikan produk berdasarkan saran yang diperoleh dari ahli materi dan media. Adapun hasil validasi ahli terhadap buku ajar tematik integratif berbasis discovery learning subtema sumber energi berdasarkan angket yang telah diisi oleh ahli dapat dilihat pada gambar 1 berikut ini.

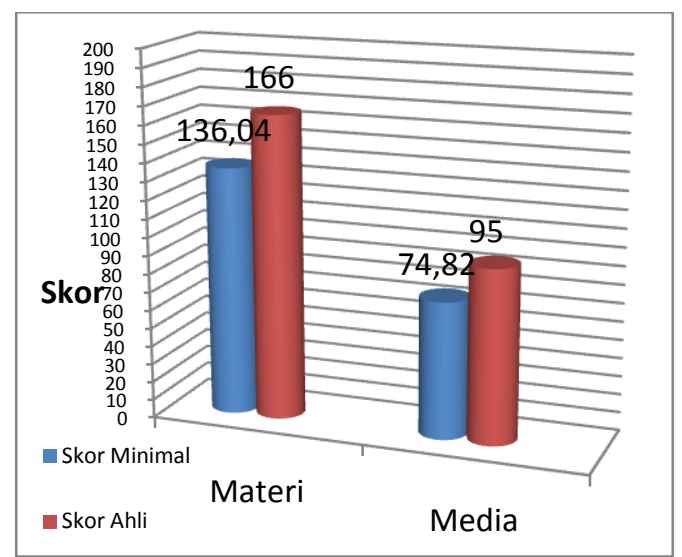

Gambar 1. Diagram Data Hasil Kelayakan Buku Ajar Tematik Integratif

\section{Hasil Uji Coba Produk}

Data hasil uji coba produk terdiri dari hasil uji coba awal, uji coba lapangan dan uji pelaksanaan lapangan. Uji coba awal dilakukan setelah melakukan validasi kepada ahli. Data yang diperoleh pada uji coba awal dan uji coba lapangan berupa data dari angket respons guru dan respons peserta didik terhadap buku ajar, sedangkan data uji pelaksanaan lapangan diperoleh dari lembar angket motivasi belajar dan lembar observasi karakter tanggung jawab peserta didik selama proses pembelajaran. Adapun hasil analisis rerata total skor aktual respons guru dapat dilihat pada tabel 5 berikut.

Tabel 5. Data Hasil Respons Guru pada Uji Coba Awal dan Uji Coba Lapangan

\begin{tabular}{cccc}
\hline Data & Skor Total & Nilai & Kategori \\
\hline $\begin{array}{c}\text { Uji Coba } \\
\text { Awal }\end{array}$ & 56 & B & Baik \\
$\begin{array}{c}\text { Uji Coba } \\
\text { Lapangan }\end{array}$ & 8,66 & A & Sangat Baik \\
\hline
\end{tabular}


Adapun hasil analisis rerata total skor aktual respons peserta didik dapat dilihat pada tabel 6 berikut.

Tabel 6. Data Hasil Respons Peserta Didik pada Uji Coba Awal dan Uji Coba Lapangan

\begin{tabular}{cccc}
\hline Data & $\begin{array}{c}\text { Skor } \\
\text { Total }\end{array}$ & Nilai & Kategori \\
\hline $\begin{array}{c}\text { Uji Coba } \\
\text { Awal }\end{array}$ & 56 & B & Baik \\
$\begin{array}{c}\text { Uji Coba } \\
\text { Lapangan }\end{array}$ & 9 & A & Sangat Baik \\
\hline
\end{tabular}

Adapun pengamatan motivasi belajar dan karakter tanggung jawab secara keseluruhan dapat dilihat pada tabel 7 dan tabel 8 berikut ini.

Tabel 7. Data Hasil Angket Motivasi Belajar pada Uji Pelaksanaan Lapangan

\begin{tabular}{cccc}
\hline Kelompok & $\begin{array}{c}\text { Skor } \\
\text { Total }\end{array}$ & Nilai & Kategori \\
\hline $\begin{array}{c}\text { Kontrol } \\
\text { Eksperimen } \\
1\end{array}$ & 16 & 46,61 & Baik \\
$\begin{array}{c}\text { Eksperimen } \\
2\end{array}$ & 16 & 58,71 & Sangat Baik \\
& 16 & 60,5 & Sangat Baik \\
\hline
\end{tabular}

Tabel 8. Data Hasil Observasi Karakter Tanggung Jawab pada Uji Pelaksanaan Lapangan

\begin{tabular}{cccc}
$\begin{array}{c}\text { Tanggung } \\
\text { Jawab } \\
\text { tiap } \\
\text { pertemuan }\end{array}$ & $\begin{array}{c}\text { Rerata } \\
\text { Kelompok } \\
\text { kontrol }\end{array}$ & $\begin{array}{c}\text { Rerata } \\
\text { Kelompok } \\
\text { Eksperimen } \\
\mathbf{1}\end{array}$ & $\begin{array}{c}\text { Rerata } \\
\text { Kelompok } \\
\text { Eksperimen } \\
\mathbf{2}\end{array}$ \\
\hline Pertama & 15,28 & 18 & 17,92 \\
Kedua & 15,46 & 18,10 & 18,03 \\
Ketiga & 15,53 & 18,14 & 18,14 \\
Keempat & 15,64 & 18,39 & 18,28 \\
Kelima & 15,71 & 18,35 & 18,32 \\
Keenam & 15,78 & 18,5 & 18,46 \\
\hline
\end{tabular}

Keefektifan penggunaan buku pelajaran dilihat dari perbedaan hasil motivasi belajar dan karakter tanggung jawab dari kelas kontrol dan kelas eksperimen dilakukan dengan menggunakan uji-t. Hasil analisis uji-t untuk motivasi belajar dapat dilihat pada tabel 9 berikut.
Tabel 9. Uji Beda Hasil Motivasi Belajar Peserta Didik

\begin{tabular}{ccccc}
\hline $\begin{array}{c}\text { Perbandingan tiap } \\
\text { kelompok }\end{array}$ & t hitung & t tabel & $\begin{array}{c}\text { Sig. } \\
(2- \\
\text { tailed } \\
)\end{array}$ \\
\hline $\begin{array}{c}\text { Motivasi } \\
\text { belajar }\end{array}$ & $\begin{array}{c}\text { Equal variances } \\
\text { assumed } \\
\text { Equal variances } \\
\text { not assumed } \\
2\end{array}$ & -6.899 & $-2,056$ & .000 \\
$\begin{array}{c}\text { Equal variances } \\
\text { assumed } \\
\text { Motivasi } \\
\text { belajar }\end{array}$ & -6.067 & $-2,056$ & .000 \\
\hline & $\begin{array}{c}\text { Equal variances } \\
\text { not assumed }\end{array}$ & -6.067 & $-2,056$ & .000 \\
\hline
\end{tabular}

Berdasarkan data yang diperoleh, diketahui bahwa nilai thitung pada perbandingan 1 adalah $-6,899$ lebih kecil dari tabel yang memiliki nilai $-2,056(-6,899<-2,056)$ dan signifikansi $\mathrm{P}$ $0,000<0,05$ maka $\mathrm{H}_{0}$ ditolak, sedangkan pada perbandingan 2 adalah $-6,067$ lebih kecil dari t tabel yang memiliki nilai $-2,056(-6,067<-2,056)$ dan signifikansi dan $\mathrm{P} 0,000<0,05$ sehingga $\mathrm{H}_{0}$ ditolak. Artinya, ada perbedaan antara rata-rata hasil pengamatan motivasi belajar kelas kontrol dan kelas eksperimen. Jadi, terdapat perbedaan motivasi belajar antara kelas yang menggunakan buku ajar tematik integratif berbasis discovery learning dan kelas yang menggunakan buku ajar yang biasa dipakai dari pemerintah.

Adapun uji $\mathrm{t}$ untuk nilai karakter tanggung jawab pada kelompok eksperimen dan kontrol dapat dilihat pada tabel 10 berikut ini.

Tabel 10.Uji Beda Hasil Karakter Tanggung Jawab Peserta Didik

\begin{tabular}{|c|c|c|c|c|}
\hline \multicolumn{2}{|c|}{$\begin{array}{l}\text { Perbandingan tiap } \\
\text { kelompok }\end{array}$} & \multirow{2}{*}{$\begin{array}{l}\text { t hitung } \\
-8.051\end{array}$} & \multirow{2}{*}{$\begin{array}{c}\mathrm{T} \text { tabel } \\
-2,056\end{array}$} & \multirow{2}{*}{ 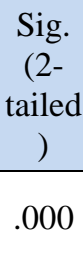 } \\
\hline $\begin{array}{c}1 \\
\text { Karakter }\end{array}$ & $\begin{array}{c}\text { Equal variances } \\
\text { assumed }\end{array}$ & & & \\
\hline $\begin{array}{l}\text { Tanggun } \\
\text { g Jawab }\end{array}$ & $\begin{array}{c}\text { Equal variances } \\
\text { not assumed }\end{array}$ & -8.051 & $-2,056$ & .000 \\
\hline $\begin{array}{c}2 \\
\text { Karakter }\end{array}$ & $\begin{array}{c}\text { Equal variances } \\
\text { assumed }\end{array}$ & -8.466 & $-2,056$ & .000 \\
\hline $\begin{array}{l}\text { Tanggun } \\
\text { g Jawab }\end{array}$ & $\begin{array}{c}\text { Equal variances } \\
\text { not assumed }\end{array}$ & -8.466 & $-2,056$ & .000 \\
\hline
\end{tabular}

Berdasarkan data yang diperoleh, diketahui bahwa nilai thitung pada perbandingan 1 adalah -8,051 lebih kecil dari $t$ tabel yang 
memiliki nilai $-2,056(-8,051<-2,056)$ dan signifikansi dan $\mathrm{P} 0,000<0,05$ maka Ho ditolak, sedangkan pada perbandingan 2 adalah $-8,466$ lebih kecil dari $\mathrm{t}$ tabel yang memiliki nilai $-2,056$ $(-8,466<-2,056)$ dan signifikansi dan P $0,000<$ 0,05 sehingga $\mathrm{Ho}$ ditolak. Artinya, ada perbedaan antara rata-rata hasil pengamatan karakter tanggung jawab kelas kontrol dan kelas eksperimen. Jadi, terdapat perbedaan karakter tanggung jawab antara kelas yang menggunakan buku ajar tematik integratif berbasis discovery learning dan kelas yang menggunakan buku ajar yang biasa dipakai dari pemerintah.

Buku ajar tematik integratif berbasis discovery learning yang dikembangkan dalam penelitian ini layak digunakan dalam pembelajaran di SDN 4 Krandegan. Sebelum diujicobakan di lapangan, produk buku ajar tematik integratif berbasis discovery learning harus dinilai kelayakannya oleh para ahli, yaitu ahli materi dan ahli media. Penilaian yang diperoleh oleh ahli materi adalah 166 dengan nilai B kategori "baik" dan ahli media memperoleh skor 95 dengan nilai A kategori "sangat baik" kemudian dapat dilanjutkan ke tahap berikutnya yaitu menguji keefektifannya di lapangan.

Data kelayakan lain buku ajar tematik integratif berbasis discovery learning di lapangan dilakukan tiga uji coba produk, yaitu uji coba lapangan awal, uji coba lapangan, dan uji pelaksanaan lapangan. Pada pelaksanaan uji coba produk dan uji coba lapangan awal, skor respons guru dan respons peserta didik semakin meningkat. Selain itu, data yang diperoleh dari uji coba lapangan dari lembar observasi motivasi belajar dan karakter tanggung jawab peserta didik pada kelompok kontrol (menggunakan buku ajar dari pemerintah) dan kelompok eksperimen memiliki motivasi belajar dan karakter tanggung jawab yang tinggi dibandingkan dengan kelompok kontrol. Skor respons guru pada saat uji coba lapangan awal pada aspek standar materi buku ajar memperoleh skor 37 dengan kriteria baik, sedangkan pada aspek standar bahasa buku ajar memperoleh skor 19 dengan kriteria sama yaitu baik. Berdasarkan skor data yang diperoleh dapat diartikan bahwa guru menilai buku ajar tematik integratif berbasis discovery learning sudah layak.

Berdasarkan data respons peserta didik pada aspek kemenarikan buku ajar tematik integratif memperoleh skor 3,33 dengan kriteria sangat baik, aspek kejelasan buku ajar tematik integratif memperoleh skor 2,66 dengan kriteria sangat baik, aspek kemudahan memahami buku ajar tematik integratif memperoleh skor 1 dengan kriteria sangat baik dan aspek dapat memfasilitasi pemahaman materi memperoleh skor 1,66 dengan kriteria sangat baik. Berdasarkan skor data yang diperoleh dapat dikatakan bahwa buku ajar tematik integratif berbasis discovery learning layak dari respons peserta didik pada uji coba awal.

Selanjutnya, pada tahapan uji coba lapangan berdasarkan data respons guru pada aspek materi buku ajar diperoleh skor 43 dengan kriteria sangat baik dan aspek standar bahasa buku ajar diperoleh skor 24 dengan kriteria sangat baik. Berdasarkan skor yang diperoleh dari respons guru tersebut dapat dikatakan bahwa buku ajar tematik integratif berbasis discovery learning layak dilanjutkan ke tahap uji pelaksanaan lapangan. Data lain tentang respons peserta didik pada saat uji coba lapangan pada aspek kemenarikan buku ajar tematik integratif memperoleh skor 3,6 dengan kriteria sangat baik, aspek kejelasan buku ajar tematik integratif memperoleh skor 2,7 dengan kriteria sangat baik, aspek kemudahan memahami buku ajar tematik integratif skor 0,9 dengan kriteria sangat baik dan aspek memfasilitasi pemahaman materi memperoleh skor 1,8 dengan kriteria sangat baik. Berdasarkan skor data yang diperoleh buku ajar tematik integratif berbasis discovery learning dapat dikatakan layak dari segi respons peserta didik pada saat uji coba lapangan.

Data kelayakan pada saat uji pelaksanaan lapangan diperoleh dari respons guru yaitu pada aspek materi buku ajar memperoleh skor 44 dengan kriteria sangat baik dan aspek standar bahasa buku ajar memperoleh skor 25 dengan kriteria sangat baik, sedangkan data respons peserta didik pada aspek kemenarikan buku ajar tematik integratif memperoleh skor 4 dengan kriteria sangat baik, aspek kejelasan buku ajar tematik integratif memperoleh skor 2,82 dengan kriteria sangat baik, aspek kemudahan memahami buku ajar tematik integratif memperoleh skor 1 dengan kriteria sangat baik, aspek yang terakhir adalah dapat memfasilitasi pemahaman materi memperoleh skor 2 dengan kriteria sangat baik.

Data keefektifan diperoleh dari hasil angket motivasi belajar dan observasi karakter tanggung jawab. Adapun hasil angket yang diperoleh di kelas kontrol memperoleh rata-rata 
skor 46,61, di kelas eksperimen 1 memperoleh rata-rata skor 58,71 dan di eksperimen 2 memperoleh rata-rata skor 60,5. Hasil observasi karakter tanggung jawab diperoleh dari kelas eksperimen 1, memperoleh skor 15,89 pada saat observasi awal, sedangkan pada observasi akhir memperoleh skor 18,5. Pada kelas eksperimen 2 memperoleh skor 16,21 pada observasi awal, sedangkan pada observasi akhir memperoleh skor 18,46. Pada kelompok kontrol memperoleh skor 15 pada observasi awal sedangkan 15,78 pada observasi akhir.

Berdasarkan pembahasan di atas, buku buku tematik integratif berbasis discovery learning subtema Sumber Energi untuk peserta didik kelas III SD yang dikembangkan ini dapat dijadikan alternatif pembelajaran dilihat dari kelayakan dan keefektifan buku pelajaran tersebut. Hal ini didukung oleh hasil penelitian yang dilakukan oleh (Liu \& Wang, 2010: 28) yang menyebutkan bahwa keberhasilan pelaksanaan pembelajaran dengan bahan ajar tematik dipengaruhi oleh seberapa jauh pembelajaran tersebut direncanakan sesuai dengan kondisi dan potensi peserta didik.

Bedasarkan data keefektifan yang diperoleh bahwa buku ajar berbasis discovery learning efektif digunakan pada pembelajaran tematik integratif, karena data yang diperoleh pada kelas eksperimen lebih tinggi dibandingkan kelas kontrol. Buku ajar berbasis discovery learning yang dikembangkan meningkatkan motivasi belajar dan karakter tanggung jawab peserta didik dalam proses pembelajaran khususnya pada subtema Sumber Energi. Kegiatan-kegiatan tersebut mengacu pada kegiatan peserta didik yang berupaya menggali informasi yang diperoleh bukan hanya dari buku ajar saja, namun peserta didik berupaya berinteraksi langsung dengan orang lain dalam mencari informasi yang berkaitan dengan materi yang diajarkan.

Buku ajar berbasis discovery learning juga memfasilitasi peserta didik dengan mengarahkannya menjadi peserta didik yang aktif dan lebih memahami konsep berdasarkan temuan-temuan jawaban yang diperoleh dari orang lain yang ada di sekitar peserta didik. Hal ini sejalan dengan pendapat Bruner (Alfieri, 2010: 12) "Claimed that independent discovery increased the learner's competence motivation and that cyclically, that increase in competence motivation would encourage the learner to try to learn things independently in the future" Maksudnya adalah penemuan independen meningkatkan motivasi kompetensi peserta didik dan siklis, yang peningkatan motivasi kompetensi akan mendorong pelajar untuk mencoba belajar hal-hal secara mandiri di masa depan. Selain itu berdasarkan hasil penelitian yang dilakukan oleh Barus (2013) terlihat bahwa buku ajar yang layak dan efektif dapat dijadikan sebagai sumber belajar, sehingga guru lebih mudah dalam menyampaikan materi dan pembelajaran menjadi lebih efektif sesuai dengan tujuan yang diharapkan.

\section{PENUTUP}

Berdasarkan hasil penelitian dan pengembangan buku ajar tematik integratif berbasis discovery learning ini, dapat disimpulkan, yaitu: buku ajar tematik integratif berbasis discovery learning yang dikembangkan pada subtema Sumber Energi untuk kelas III SD Negeri 4 Krandegan layak. Kelayakan tersebut dilihat dari aspek materi dengan skor total 166 dengan nilai B dan berkategori "baik", aspek media dengan skor 95 dengan nilai A dan kategori "sangat baik", respons guru dengan skor 69 dengan nilai A dan kategori "sangat baik", respons peserta didik dengan skor 9,82 dengan nilai A dan kategori "sangat baik". Buku ajar yang dikembangkan untuk pembelajaran tematik integratif berbasis discovery learning subtema Sumber Energi untuk kelas III SD Negeri 4 Krandegan efektif. Keefektifan tersebut diperoleh dari angket motivasi belajar kelas eksperimen 1 dan 2 yaitu pada kelas IIIA dengan skor rata-rata 58,71 dengan kriteria "sangat baik" dan kelas IIIC memperoleh rata-rata skor 60,5 dengan kriteria "sangat baik". Data karakter tanggung jawab peserta didik pada kelas IIIA dan kelas IIIC diperoleh dari observasi yaitu masingmasing memperoleh skor 18,6 dan 18,46.

Hasil tersebut menunjukkan bahwa buku ajar guna meningkatkan karakter disiplin dan tanggung jawab yang dikembangkan peneliti layak digunakan sebagai sumber belajar. Pada penelitian ini, buku ajar dijadikan sebagai sumber belajar. Jadi, dengan dipergunakannya buku ajar, maka kualitas pembelajaran dapat meningkat dan tepat sesuai dengan sasaran tujuan pembelajaran.

\section{UCAPAN TERIMA KASIH}

Dengan mengucapkan alhamdulillah penulis mengucapkan terima kasih kepada Tuhan 
atas selesaianya tulisan tentang karakter ini. Selanjutnya penulis ingin mengucapkan terima kasih yang sebesar-besarnya kepada seluruh anggota dewan redaksi Jurnal Pendidikan Karakter yang mau menerima dan mengolah artikel ini hingga dimuat pada edisi sekarang.

\section{DAFTAR PUSTAKA}

Alfieri, L. 2010. Does discovery based instruction enhance learning? UMI Dissertasion, 1-40.

Arends, R.I. 2012. Learning to teach $\left(9^{\text {th }} e d\right)$. New York: Mc. Graw Hill.

Barus, Y.K. 2013. Pengembangan buku teks tematik tema permainan untuk kelas III SDN Tridadi Sleman Yogyakarta. Tesis, tidak diterbitkan, Universitas Negeri Yogyakarta, Yogyakarta.

Borg, W.R. \& Gall, M.D. 1983. Educational research: an introduction $\left(4^{\text {th }} \mathrm{ed}\right)$. London: Longman Inc.

Busch, I., et al. 2009. Two thematic units for the school curriculum: an initiative by the kinder lernen deutsch steering committee's writing team1. Scholarly Journal, (42), 170-177.

Cruickshank, D.R., Jenkins, D.B., \& Metcalf, K.K. 2012. The act of teaching. New York: Mc. Graw Hill.

Djamarah, S.B., \& Zain, A. (2010). Strategi belajar mengajar (Rev. ed). Jakarta: Rineka Cipta.

Lauermann, F. \& Karabenick, S.A. 2012. The meaning and measure of techer sense of responssibility for educational outcomes. Teaching and Teacher Education, (30), 13-16.

Liu, M.C., \& Wang, J.Y. 2010. Investigating knowledge integration in web-based thematic learning using concept mapping assessment. Educational Technology \& Society, (13), 25-39.
Majid, A. 2014. Pembelajaran tematik terpadu. Bandung: Remaja Rosdakarya.

Sari, I.P. 2014. Pengembangan buku pelajaran tematik-integratif berbasis nilai karakter disiplin dan tanggung jawab di sekolah dasar. Tesis, tidak diterbitkan, Universitas Negeri Yogyakarta, Yogyakarta.

Slavin, R.E. 2006. Educational psychology theory and practice $\left(8^{\text {th }} e d\right)$. New York: Pearson Education.

Treadwell, J.W. 2010. The impact of discovery learning in writing instruction on fifthgrade student achievement. UMI Dissertasion, 55-79. 